\title{
EXPANSION OF CYTOGENETICALLY MODIFIED FORM OF OPISTHORCHIS FELINEUS IN THE TOM RIVER BASIN
}

\author{
Nikolai N. Ilyinskikh a,b,*, Ekaterina N. Ilyinskikh a \\ aNational Research Tomsk State University, \\ Lenina Str. 38, Tomsk, 634050 Russian Federation \\ ${ }^{b}$ Siberian State Medical University, \\ Moskovsky trakt 2, Tomsk, 634050 Russian Federation \\ * e-mail: nauka-tomsk@yandex.ru
}

Received May 10, 2016;

Accepted in revised form 19 June, 2016;

Published December 30, 2016

\begin{abstract}
In 1993, karyotyping of Opisthorchis felineus sporocysts, isolated from aquatic mollusks Bithynia inflata in the industrial wastewater of the Siberian Chemical Combine discovered cytogenetically modified 12-chromosome specimens. In 2012-2013, a repeated study of the spread of these mutant trematodes in the lower course of the river Tom was carried out. It was established that specimens with sporocysts of $O$. felineus having $2 n=12$ were found in 8 of 10 places of catching. The caught goldfish were used to isolate metacercariae to infest golden hamsters in the experimental conditions. After 5 months, the hamster livers were processed to extract marita specimens and the number of chromosomes in their ovaries and testes was cytogenetically determined. The results of analysis of the spread of $O$. felineus carried out by this method showed the presence of 12-chromosome form of the Opisthorchis marita in all places of fishing out in the lower course of the river Tom. Analysis of the 12-chromosome karyotype allows to conclude that this mutation was a result of Robertsonian fusion of chromosomes 3 and 6 of 14-chromosome form of karyotype.
\end{abstract}

Keywords: Opisthorchis felineus, karyotype, Robertsonian translocation, Tom River

DOI: $10.21603 / 2500-1418-2016-1-2-65-79$.

\section{INTRODUCTION}

Opisthorchis felineus (Rivolta, 1882) trematode of Opisthorchiidae family (Braun, 1901) parasitizing at various developmental stages in aquatic mollusks of Bithyniidae family, fish of Cyprinidae family and in piscivorous mammals, including humans. Karyotype analysis of this species was carried out by Ya.V. Barshene [1], who established that $2 \mathrm{n}=14(4 \mathrm{~m}+6 \mathrm{sm}+4 \mathrm{a})$; similar results were obtained by our studies $[2,3]$. In the study of Polyakov et al. [4], diploid set of chromosomes was $2 n=14$, too, but the ratio of morphological types of chromosomes was somewhat different $(6 \mathrm{~m}+8 \mathrm{sm})$.

As a result of accident at the Siberian Chemical Combine in 1993, a significant number of radionuclides was released into the environment, contaminating local water bodies, which caused accumulation of longlived and short-lived radioactive elements in aquatic organisms [5-7]. Chromosome analysis of sporocysts of $O$. felineus, extracted from Bithynia inflata aquatic mollusks caught in SCC technological effluents, allowed to establish a significant increase in the number of trematode cells with chromosomal aberrations, as well as change in the number of chromosomes. [3] As it turned out, in one of the local SCC waste discharge sites more than $30 \%$ opistorhides had balanced reciprocal Robertsonian translocation with emergence of a couple of large submetacentric chromosomes. Karyotype formula of these cat liver flukes was $2 n=12(4 \mathrm{~m}+$ $8 \mathrm{sm})$.

The main objective of this research was to study again, 20 years after the incident, cytogenetic consequences of radioactive pollution for the population of $O$. felineus and to solve the problem of the further spread of the cat liver fluke with Robertsonian translocation the lower course of the river Tom (Russian Federation).

\section{MATERIALS AND METHODS}

During the summer period of 2012-2013, 124 specimens of Carassius auratus gibelio goldfish were caught. This species is one of the most frequently encountered in catches at all points of the lower course of the river Tom, and the only species of fish present in catches from the neighboring waste discharge site of the Siberian Chemical Combine. Mature fish were caught in 10 places of the lower course of the river Tom and its tributary, the river Romashka (Fig. 1).

Metacercariae were isolated from fish muscles with the use of the method described in the study of D.P. Kudryavtsev [8]. Invasion of 120 golden hamsters by giving 30-50 metacercariae of $O$. felineus into a throat. After 50 days, Opisthorchis marita specimens were isolated from the liver of hamsters at the prosection. Chromosomal preparations from marita specimens

Please cite this article in press as: Ilyinskikh N.N., Ilyinskikh E.N. Expansion of cytogenetically modified form of Opisthorchis felineus in the Tom river basin. Science Evolution, 2016, vol. 1, no. 2, pp. 65-79. doi: 2500-1418-2016-1-2-65-79.

Copyright (C) 2016, KemSU. This is an open access article distributed under the terms of the Creative Commons Attribution 4.0 International License (http:// creativecommons.org/licenses/by/4.0/), allowing third parties to copy and redistribute the material in any medium or format and to remix, transform, and build upon the material for any purpose, even commercially, provided the original work is properly cited and states its license. This article is published with open access at http:/ science-evolution.ru/ 
were prepared by the method of Terasaki [9] with some modifications. Live marita specimens of $O$. felineus were placed in $0.005 \%$ colchicine physiological saline solution for 3 hours at $37^{\circ}$. Then their testes and ovaries were removed and placed in $0.6 \%$ hypotonic sodium citrate solution. Then cells were fixed for 30 minutes in a Carnoy's solution (methanol + glacial acetic acid in the ratio of 1: 1). Furthermore, a drop of cell suspension was placed on a chilled wet glass and dried by hot air flow with a hair dryer.

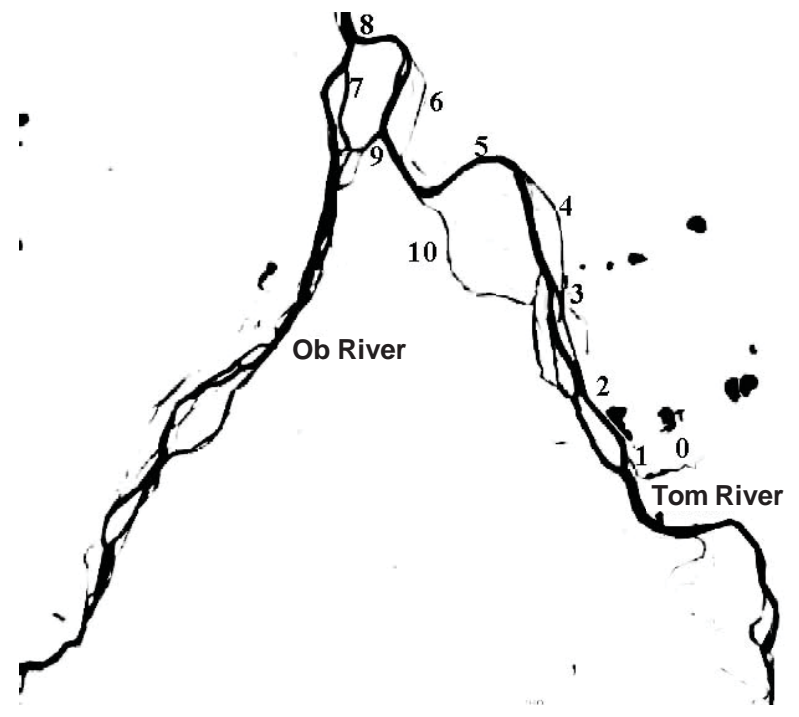

Fig. 1. Schematic map of places of catching Carassius auratus gibelio goldfish and Bithynia inflata mollusks in the Tom river basin.

Places of catching fish and mollusks: 0 - SCC waste settling ponds at the river Romashka; - Romashka river mouth; 2 - near the village of Chernilschikovo; 3 - near the settlement of Samus; 4 - near the village of Kizhirovo; 5 - near the village of Orlovka; 6 Labaznaya branch; 7 - Bitenevskaya branch; 8 - Tom mouth; 9 - Chatskaya branch; 10 - near the village of Nagornny Ishtan.

In another series of studies, chromosome preparations were obtained from sporocysts of O. felineus isolated from Bithynia inflata aquatic mollusks - one of the main intermediate hosts of O. felineus in West Siberia [10]. 864 mollusk specimens were caught at the bottom of the river Tom and its tributary the river Romashka. Examination of these mollusks showed that in $53.7-94.5 \%$ of cases, depending on the catching location, they were infested by the larvae of $O$. felineus. Species belonging to O. felineus was determined by cercariae isolated from infested mollusks. For chromosomal preparations of O. felineus, caught mollusks were placed in $0.005 \%$ colchicine solution for 12 hours. Water for the solution was taken from the river. Chromosomes preparations were prepared of sporocysts. For this purpose, the isolated larvae were treated with colchicine and placed for 1 hour in distilled water, which was changed three times. Fixation was performed in Carnoy's mixture (3 parts of ethanol per one part of glacial acetic acid). In all cases, the preparations were stained according to Romanovsky-Giemsa method with the use of Sorensen's phosphate buffer $(\mathrm{pH}$ 6.8) diluted at a ratio of 1:50 for $15 \mathrm{~min}$. The chromosome study was conducted with the use Reichert NP-1640 microscope (Austria) and $10 \times 90$ magnification. The karyotyping used classification of chromosome types proposed by Ya.V. Barshene [1] and updated by A.V. Polyakov et al. [4].

\section{RESULTS AND DISCUSSION}

Our findings, as well as results of the other research $[1,4,11]$ indicate that the karyotype of $O$. felineus normally has 14 chromosomes. From our point of view, the most interesting of them is our observation of emergence and spread of specimens of $O$. felineus with 12-chromosome karyotype as a result of Robertsonian translocation of acrocentric chromosomes (Fig. 2).

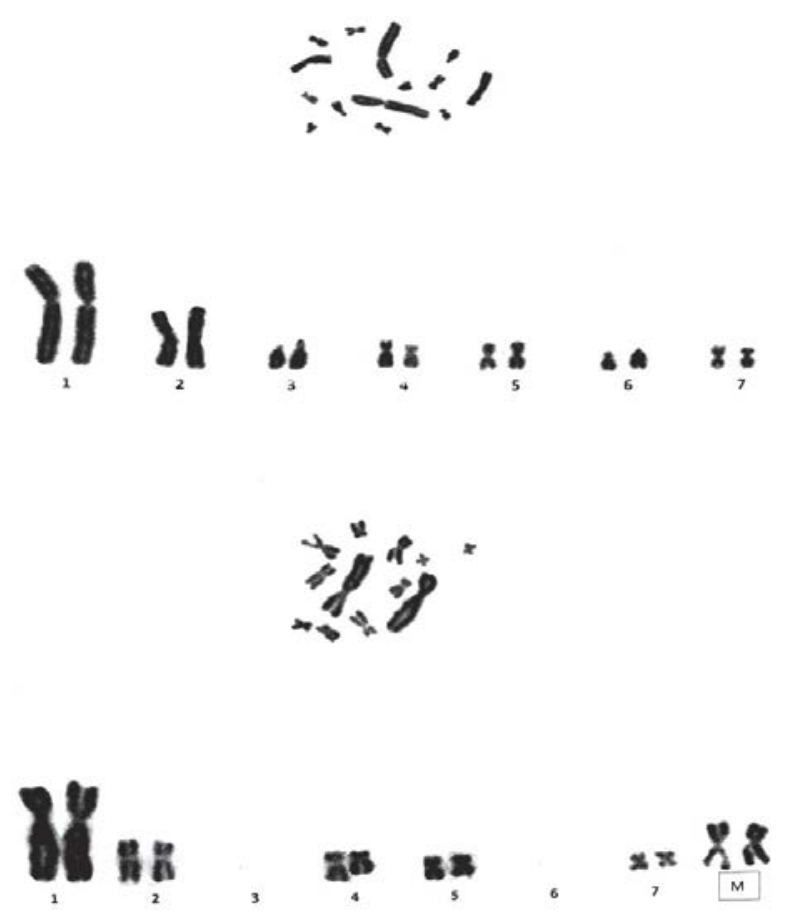

Fig. 2. Karyotypic features of Opisthorchis felineus with $2 n=12$ and $2 n=14$

According to karyological data, emergence of 12chromosome variant is associated with centric fusion of 3 and 6 chromosomes of 14-chromosome karyotype of O. felineus. The results of this study suggest a significant spread of a modified form of $O$. felineus in the lower course of the river Tom for the period from 1993 to 2013 (Table 1).

Analysis of incidence of 12-chromosome forms of sporocysts of cat liver flukes isolated from Bithynia inflata snails shows that in 1993 the main trematode spread areas were the river Romashka and stretch of the river Tom near the village of Chernilschikovo. 12-chromosome variant of Opisthorchis was not found downstream. Catching of snails in 2013 discovered occurrence of a mutant form of Opisthorchis sporocysts in the river Tom, up to the mouth.

Analysis of $O$. felineus marita chromosomes (Table 2) derived by artificial infestion of golden hamsters by 
Table 1. Comparative incidence of intact and mutant forms of $O$. felineus sporocysts in the lower course of the river Tom in 1993 and 2013

\begin{tabular}{|c|c|c|c|c|c|c|c|c|}
\hline \multirow{4}{*}{$\begin{array}{l}\text { Snails catching places } \\
\text { Bithynia inflata }\end{array}$} & \multicolumn{8}{|c|}{ Number of $O$. felineus sporocysts } \\
\hline & \multicolumn{4}{|c|}{$2 n=14$} & \multicolumn{4}{|c|}{$2 n=12$} \\
\hline & \multicolumn{2}{|c|}{ In 1993} & \multicolumn{2}{|c|}{ In 2013} & \multicolumn{2}{|c|}{ In 1993} & \multicolumn{2}{|c|}{ In 2013} \\
\hline & abs. & $\%$ & abs. & $\%$ & abs. & $\%$ & abs. & $\%$ \\
\hline $0-$ SCC waste settling ponds & 29 & 61.7 & 48 & 66.7 & 18 & 37.3 & 24 & 33.3 \\
\hline 1 - Romashka river mouth & 34 & 73.9 & 36 & 66.7 & 12 & 26.1 & 18 & 33.3 \\
\hline 2 - near the village of Chernilschikovo & 23 & 69.7 & 24 & 55.8 & 10 & 30.3 & 19 & 44.2 \\
\hline 3 - near the settlement of Samus & 20 & 100 & 39 & 58.2 & 0 & 0 & 28 & 41.8 \\
\hline 4 - near the village of Kizhirovo & 41 & 100 & 42 & 95.5 & 0 & 0 & 2 & 4.5 \\
\hline 5 - near the village of Orlovka & 25 & 100 & 32 & 88.9 & 0 & 0 & 4 & 11.1 \\
\hline 6 - Labaznaya branch & 20 & 100 & 14 & 82.4 & 0 & 0 & 3 & 7.3 \\
\hline 7 - Bitenevskaya branch & 32 & 100 & 26 & 86.7 & 0 & 0 & 4 & 3.3 \\
\hline $8-$ Tom river mouth & 34 & 100 & 24 & 92.3 & 0 & 0 & 2 & 7.7 \\
\hline 9-Chatskaya branch & 30 & 100 & 13 & 100 & 0 & 0 & 0 & 0 \\
\hline 10 - near the village of Nagorny Ishtan & 31 & 100 & 22 & 100 & 0 & 0 & 0 & 0 \\
\hline
\end{tabular}

Table 2. Incidence of intact and mutant marita forms of $O$. felineus in the lower course of the river Tom

\begin{tabular}{|c|c|c|c|c|c|}
\hline \multirow{3}{*}{ Orfe catching places } & \multirow{3}{*}{$\begin{array}{l}\text { Number of marita } \\
\text { specimens studied } \\
\text { (abs.) }\end{array}$} & \multicolumn{4}{|c|}{ Number of marita $O$. felineus } \\
\hline & & \multicolumn{2}{|c|}{$2 n=14$} & \multicolumn{2}{|c|}{$2 n=12$} \\
\hline & & abs. & $\%$ & abs. & $\%$ \\
\hline 0 - SCC waste settling ponds & 34 & 29 & 85.3 & 5 & 14.7 \\
\hline 1 - Romashka river mouth & 42 & 34 & 81.0 & 8 & 19.0 \\
\hline 2 - near the village of Chernilschikovo & 32 & 23 & 71.9 & 9 & 28.1 \\
\hline $3-$ near the settlement of Samus & 28 & 20 & 71.4 & 8 & 28.6 \\
\hline 4 - near the village of Kizhirovo & 41 & 41 & 90.9 & 4 & 9.1 \\
\hline $5-$ near the village of Orlovka & 29 & 25 & 86.2 & 4 & 13.8 \\
\hline 6 - Labaznaya branch & 28 & 20 & 71.4 & 8 & 28.6 \\
\hline 7 - Bitenevskaya branch & 34 & 32 & 94.1 & 2 & 5.9 \\
\hline $8-$ Tom river mouth & 42 & 34 & 81.0 & 8 & 19.0 \\
\hline 9-Chatskaya branch & 36 & 30 & 83.3 & 6 & 16.7 \\
\hline 10 - near the village of Nagorny Ishtan & 38 & 31 & 81.6 & 7 & 18.4 \\
\hline
\end{tabular}

metacercariae of the parasite isolated from the caught goldfish showed that spread of this trematode is much wider and reached Chatskaya branch and Nagorny Ishtan, which are directly connected with the river Ob (Fig. 1).

It is shown that opistorhide larvae are very sensitive to radiation that even allows authors [12] to recommend to decontaminate affected metacercariae fish by irradiation. Comparative analysis of chromosome numbers in trematodes showed a tendency to a decrease in the number of chromosomes in evolution of their karyotype $[1,13]$. Some papers proposed karyotype with 19 pairs of acrocentric chromosomes as the ancestral karyotype of trematodes. S. Ono [14] believes that evolutionary transformations often proceed by reducing the number of chromosomes in the karyotype due to Robertsonian translocations. Some scientists $[13,15]$ also suggest that evolution of the trematode karyotype form proceeds in the form of centric mergers. A significant number of 12-chromosome trematodes of $O$. felineus in the lower course of the river Tom speaks in favor of the assumption that these species in the ecologically unfavorable situation have some advantages over the normal 14-chromosome $O$. felineus.
There is an opinion that species having a large number of chromosomes are more radiosensitive in the karyotype $[16,17]$. According to A.V. Toropov [5], $9 \gamma$-emitting man-made radionuclides were found in the ichthyofauna objects of the lower course of the river Tom. At the same time, ${ }^{65} \mathrm{Zn}$ has the highest absolute level (1650 $\mathrm{Bq} / \mathrm{kg}$ ) and the highest factor of build-up in fish organs and tissues in relation to water. Goldfish (Carassius auratus gibelio) accumulates man-made radionuclides more than other representatives of the ichthyofauna. Besides the rapid spread of 12-chromosome species is due, apparently, to the fact that cat liver flukes in larval development period multiply rapidly by parthenogenesis, and sporocysts give rediae, and rediae give the next stage of larval development - cercariae, in which case one sporocyst may parthenogenetically produce several thousands of descendants $[2,10]$. Therefore, the rapid spread of mutant forms of the parasite is possible. It is known that among 5 species of Opisthorchiidae family (Opisthorchis felineus $2 \mathrm{n}=14$ (Rivolta, 1884), Opisthorchis viverrini $2 \mathrm{n}=12$ (Poirier, 1886), Metorchis xanthosomus $2 \mathrm{n}=14$ (Creplin, 1846), Metorchis bilis 2n=14 (Braun, 1890), Clonorchis 
sinensis $2 \mathrm{n}=14$ (Cobbold, 1875), only one species, O. viverini, has 12-chromosome karyotype [18]. It was found that the chromosome 3 of Opisthorchis viverrini occurred during the merger of chromosomes 3 and 7 of a possible ancestral karyotype of opistorhides [19]. We do not exclude the possibility of "introduction" of O. viverini in the river Tom, but in this case, it is difficult to explain the fact that it occurred in the radioactive contamination zone, but not in an environmentally safe part of the reservoir. In this regard, we tend to believe that long-term radiation effects on the population of $O$. felineus in the radioactive waste dumping area may have led to occurrence and spread of 12-chromosome species of this parasite. It is possible that we are dealing with a new kind of opisthorchide flukes. It is known that Opisthorchis group includes a several dozen of species. Some scientists believe that species of $O$. felineus may be divided taxonomically into separate subspecies. [10]. The same is evidenced by differences in clinical manifestations of the humans opisthorchiasis observed in the Yenisei and Ob-Irtysh regions of Siberia [20]. In this connection, it is of interest to compare the morphology, development cycles, and degree of pathogenicity for intermediate and main hosts, including those for human of 14 and 12-chromosome variants of $O$. felineus in order to determine degree of taxonomic independence of these groups of trematodes.

\section{CONCLUSION}

In 1993, karyotyping of Opisthorchis felineus sporocysts, isolated from aquatic mollusks Bithynia inflata in the industrial wastewater of the Siberian Chemical Combine discovered cytogenetically modified 12-chromosome specimens. In 2012-2013, a repeated study of the spread of these mutant trematodes in the lower course of the river Tom was carried out. It was established that specimens with sporocysts of $O$. felineus having $2 \mathrm{n}=12$ were found in 8 of 10 places of catching. The caught goldfish were used to isolate metacercariae to infest golden hamsters in the experimental conditions. After 5 months, the hamster livers were processed to extract marita and the number of chromosomes in their ovaries and testes was cytogenetically determined. The results of analysis of the spread of $\mathrm{O}$. felineus carried out by this method showed the presence of 12-chromosome form of the Opisthorchis marita in all places of fishing out in the lower course of the river Tom. Analysis of the 12-chromosome karyotype allows to conclude that this mutation was a result of Robertsonian fusion of chromosomes 3 and 6 of 14-chromosome form of karyotype.

\section{ACKNOWLEDGEMENT}

This study was supported financially by grant no. 10190 of the Russian Humanitarian Science Foundation and grant no. 16-44-700149 of the Russian Foundation for Basic Research.

\section{REFERENCES}

1. Barshene Ya.V. Khromosomnye kompleksy trematod [Chromosome complexes of Trematoda]. Parazitologiya [Parasitology], 1993, vol. 27, pp. 336-352.

2 Beer S.A. Biologiya vozbuditelya opistorkhoza [The Biology of Opisthorchiasis Agent]. Moscow: Tovarishchestvo nauchnykh izdaniy KMK Publ., 2005. 336 p.

3. Viktorov A.G. Radiochuvstvitel'nost' i radiopatologiya dozhdevykh chervey, ikh ispol'zovanie v bioindikatsii radioaktivnykh zagryazneniy [Radio-sensitivity and radiopathology of earthworms and their use as bioindication of radioactive contamination]. Bioindikatsiya radioaktivnykh zagryazneniy [Bioindication of radioactive contamination.] Moscow: Nauka Publ., 1999, pp. 213-217.

4. Dubinin N.P. Evolyutsiya populyatsiy i radiatsiya [Evolution of Populations and Radiation] Moscow: Atomizdat Publ., 1996. $743 \mathrm{p}$.

5. Zadesenets K.S. Strukturno-funktsional'naya organizatsiya khromosom opistorkhid. Avtoref. diss. kand. biol. nauk. [Structural and functional organization of opistorhid chromosomes. Cand. biol. sci.]. Novosibirsk, 2013. 26 p.

6. Il'inskikh N.N., Vengerovskiy A.I., Lepekhin A.V., Zuevskiy V.P., Il'inskikh E.N. Meditsinskaya parazitologiya [Medical Parasitology]. Tomsk: Pechatnyy dvor Publ., 2001. 334 p.

7. Il'inskikh N.N., Il'inskikh I.N., Il'inskikh E.N. Evolyutsiya khromosomnogo nabora trematod Opisthorchis felineus, otlovlennykh v mestakh sbrosa radioaktivnykh otkhodov Sibirskogo khimicheskogo kombinata [Evolution of the chromosome set of Opisthorchis felineus trematode, caught in radioactive waste dumping sites of Siberian Chemical Combine]. Mezhdunarodnaya nauchnoprakticheskaya konferentsiya "20 let Chernobyl'skoy katastrofy: ekologicheskie i sotsial'nye uroki [International Scientific and Practical Conference: 20 years after Chernobyl: Social and Economic Problems]. 2006, Moscow: Nauka Publ., pp. 59-63.

8. Kudryavtsev D.P. Metodicheskie podkhodya po vydeleniyu metatserkariev opistorkhov iz ryby i modelirovanie opistorkhoza na laboratornykh zhivotnykh [Methodological approaches to allocate opisthorchis metacercariae from fish and modeling opisthorchiasis on laboratory animals]. Fundamental'nye nauki - meditsine [Basic Sciences of Medicine]. Tomsk: SibSMU Publ., 1989, p. 41-44.

9. Ono S. Geneticheskie mekhanizmy progressivnoy evolyutsii [Genetic mechanisms of progressive evolution]. Moscow: Mir Publ., 1973. $227 \mathrm{p}$.

10. Polyakov A.V., Katokhin A.V., Bocharova T.A., Romanov K.V., L’vova K.N., Bonina O.M., Yurlova N.I., Mordvinov V.A. Sravnitel'nyy analiz Opisthorchis felineus iz Zapadnoy Sibiri [Comparative analysis of karyotypes of Opisthorchis felineus from West Siberia]. Sibirskiy ekologicheskiy zhurnal [Siberian Journal of Ecology], 2010, vol.1, pp. 3-6.

11. Rikhvanov L.P. Obshchie i regional'nye problemy radioekologii [General and regional problems of radioecology]. Tomsk: Tomsk Polytechnic University Publ., 1997. 384 p.

12. Romanenko L.N. Morfologiya khromosom Opisthorchis felineus (Rivolta, 1884) [Chromosome morphology in Opisthorchis felineus]. Mater. nauchn. konf. Vsesoyuz. o-va gel'mintol. [Proceedings of the scientific conference of the All-Union Society of Helminthologists]. Moscow: Nauka Publ., 1973, pp. 183-188. 
13. Toropov A.V. Nakoplenie tekhnogennykh radionuklidov komponentami ekosistemy nizhney Tomi. Avtoref. diss. kand. biol. nauk. [Accumulation of man-made radionuclides in lower Tom ecosystem components. Cand. biol. sci. thesis]. Novosibirsk, 2006.24 p.

14. Grossman A.I., Short R.B., Cain G.D. Karyotype evolution and sex chromosome differentiation in Schistosomes (Trematoda, Schistosomatidae). Chromosoma, 1981, vol. 84, p.413-430.

15. Ilyinskikh N.N., Ilyinskikh I.N., Porovskiy V.A., Natarajan A.T., Suskov I.I., Smirenniy L.N., Ilyinskikh E.N. Biodosimetry results obtained by various cytogenetic methods and electron spin resonance spectrometry among inhabitants of a radionuclide contaminated area around the Siberian Chemical Plant (Tomsk-7). Mutagenesis, 1999, vol. 14, pp. 473-478.

16. Ilyinskikh E.N., Novitskiy V.V., Urazova L.N., Isayeva T.M., Ilyinskikh I.N., Ilyinskikh N.N. Assessment of the relationship of chronic opisthorchiasis to Epstein-Barr virus infection as well as some cytogenetical and immunological parameters in two comparable Siberian regions. Environ. Toxicol, 1999, vol. 14, pp. 414-424.

17. Short R.B., Liberatos J.D., Teehan W.H., Bruce J.I. Conventional Giemsa-stained and C-banded chromosomes of seven strains of Schistosoma mansoni. J Parasitol. 1989, vol. 75, pp. 920-926.

18. Song C.C., Duan Y.F., Shou G.C., Zhu H. Studies on the use of cobalt-60 gamma irradiation to control infectivity of Clonorchis sinensis metacercariae. Southeast Asian J Trop Med Public Health, 1992, vol. 23, pp. 71-76

19. Terasaki K. Studies on Chromosomes of the lung flukes in Japan. Jpn J Parasitol., 1977, vol. 26, pp. 222-229.

20. Zadesenets K.S., Karamysheva T.V., Katokhin A.V., Mordvinov V.A., Rubtsov N.B. Distribution of repetitive DNA sequences in chromosomes of five opisthorchid species (Trematoda, Opisthorchiidae). Parasitol Int., 2012, vol. 61, pp. 84-86. doi: 10.1016/j. parint.2011.06.027

\section{Nikolai N. Ilyinskikh}

Dr.Sci.(Biol.), Professor, Head of the Department of Biology and Genetics, National Research Tomsk State University, Tomsk, Russian Federation

\section{Ekaterina N. Ilyinskikh}

Dr.Sci.(Med.), Professor, Department of Infectious Diseases and Epidemiology, Siberian State Medical University" of the Ministry of Healthcare, Tomsk, Russian Federation 


\title{
INNOVATION APPROACH TO OBTAIN THE PACKED RED CELLS FROM THE SLAUGHTER ANIMAL BLOOD
}

\author{
Alexandr V. Izgarishev *, Konstantin V. Karchin, Natalia V. Izgarisheva
}

Kemerovo Institute of Food Science and Technology (University), Stroiteley blvd. 47, Kemerovo, 650056 Russian Federation

Received May 2, 2016;

Accepted in revised form June 10, 2016;

Published December 30, 2016

\begin{abstract}
This paper is aimed to develop stabilizers with the conserving effect that helps to prolong the expiry date with the blood stabilization up to the relevant processing, including the fractionation characteristic selection. Theoretical and experimental studies are performed to comply with the tasks at hand at the "Bionanotechnology" Chair of the Kemerovo Institute of Food Science and Technology (University). The entire research cycle consisted of several correlated stages. The national and international literature available was analyzed to state objectives and tasks at the first stage. Whole blood stabilization parameters are selected with the concurrent conservation to improve the stability of erythrocyte membranes. The best value of the separation factor is selected wherein the application condition of high separation factor values is taken as the baseline for the blood fractionation. The process of citric acid influence is analyzed as the preservative agent on the blood viscosity, blood $\mathrm{pH}$ and total bacterial content. A calibration dependence graph of the separating unit rotation velocity (separator, centrifuge) is worked out of the unit rotation radius. The fractional composition of the derived protein components of red blood cells of the bovine cattle and porcine bloods is analyzed to prove the benefit of fractionation characteristics obtained. The following fractions are revealed in the packed red cells as follow: haptoglobin, fibrinogen, globulin, one of its three forms, hemoglobin, the protein of the platelet-leukocyte group.
\end{abstract}

Keywords: fractionation, separation factor, blood proteins, packed red cells, heme iron

DOI: $10.21603 / 2500-1418-2016-1-2-70-77$.

\section{INTRODUCTION}

Iron-deficiency anemia is one of the most common human diseases. Pregnant and children aged up to 8 are most susceptible to this disease. As a result, this disease can result in the fertility reduction and an increase in children mortality and serious diseases. To prevent the disease consequences, new therapeutic and preventive products should be investigated and developed to manage the iron deficiency anemia [1].

To date, of all patents relating to iron deficiency anemia management and prevention, only about onefourth are based on the use of heme iron. It is noted also that since 2007, the production of new drugs in this area is lowered. Alimentary albumin is used in many medical products to prevent the iron deficiency that is prepared from the whole blood of slaughter animals, rather than the specially isolated hemoglobin. When such products are absorbed in the body, one is at the risk to absorb the excess amount of allergy-causing components along with nutrient substances, that are mainly leukocytes and modifications thereof to remain in the final product [2-4].

As per the data provided by the Federal Institute for Industrial Property of Russia, about 100 patents only are registered to manage the iron deficiency anemia. Herewith, the majority of patents are valid for over 10 years. More than half of patents relate to developments in food industry, while remaining ones relate to pharmacy, medicine and veterinary sciences. About a quarter of patents focus on researches to manage the iron deficiency anemia using the heme iron, while the rest represent products with various iron complexes in formulation as follow: lactates and sulfates, iron ions, iron oxides and iron sulfate [5].

$20 \%$ patents propose medications to manage the iron deficiency anemia, $80 \%$ patents offer products of therapeutic and preventive effect with the high content of iron in various forms [6]. In addition, such products are additionally saturated with vitamins and mineral nutrients.

Thus, the effective prevention of the iron deficiency anemia requires researches in the field to derive the high quality stock for materials for products rich in digestible iron, that is, as the heme iron.

The blood of slaughter animals is known for relatively rich water activity, the moisture mass fraction and protein. This is to prove its easy degradation in the lack of the adequate conservation and stabilization.

\footnotetext{
Please cite this article in press as: Izgarishev A.V., Karchin K.V., Izgarisheva N.V. Innovation approach to obtain the packed red cells from the slaughter animal blood. Science Evolution, 2016, vol. 1, no. 2, pp. 70-77. doi: 10.21603/2500-1418-2016-1-2-70-77.

Copyright (C) 2016, KemSU. This is an open access article distributed under the terms of the Creative Commons Attribution 4.0 International License (http:// creativecommons.org/licenses/by/4.0/), allowing third parties to copy and redistribute the material in any medium or format and to remix, transform, and build upon the material for any purpose, even commercially, provided the original work is properly cited and states its license. This article is published with open access at http:// science-evolution.ru/
} 
It is therefore urgent to develop a solution that facilitates stabilization (prevent of clotting) with the concurrent conservation $[7,8]$.

The research is aimed to develop stabilizers with the preservative effect that allow extending the shelf life during blood stabilization prior to appropriate processing, as well as the selection of the fractionation characteristics with primary isolation of the heme iron.

\section{OBJECTS AND METHODS OF STUDY}

The following is used as the research item:

- the whole blood of the bovine cattle and pigs obtained as per requirements of SanPiN 2.3.2.1078-01;

- alimentary acetic acid as per GOST 6968-76;

- alimentary citric acid as per GOST 90-2004;

- 5.5 aquatic sodium citrate, dietary, as per GOST 31227-2004;

- drinking water as per GOST 2874-82;

- auxiliary raw stock and materials that meet requirements of the applicable document or those imported (sodium and potassium hydroxide, hydrochloric acid, citric acid, mineral salts) and allowed for use in the food industry.

The mass fraction of iron is determined as per GOST 30648.3-99. To determine the iron content, 1.0-1.2 g of sample is carefully carbonized in the porcelain crucible in the incinerator until red hot. The ash is dissolved in 10 $\mathrm{ml}$ of hydrochloric acid, diluted to $1: 1$, and the resulting solution is evaporated to dryness in the water bath. The dry residue is redissolved in $20 \mathrm{ml}$ of hydrochloric acid (1:1) and placed in the conical flask of $250 \mathrm{ml}$ in volume by rinsing the crucible with $10-15 \mathrm{ml}$ of distilled water. Then, $1.5 \mathrm{~g}$ of potassium iodide is added to the flask, the flask is sealed with a glass stopper and allowed to leave for 5 minutes, and then $70 \mathrm{ml}$ of distilled water is added to titrate with $0.1 \mathrm{~N}$. of sodium thiosulfate solution $(1 \mathrm{ml}$ of $0.1 \mathrm{~N}$. sodium thiosulfate solution corresponds to $5.58 \mathrm{mg}$ of iron). The iron content (\%) is determined by the formula (1),

$$
\mathrm{X}=5.58 \cdot \mathrm{a} \cdot \mathrm{K} \cdot 100 / \mathrm{b},
$$

where a - amount of sodium thiosulfate milliliters consumed to titrate the sample weighed portion; $\mathrm{K}$-correcting factor to $0.1 \mathrm{~N}$. solution of sodium thiosulfate; b-sample weighed portion, in $\mathrm{mg}$.

The stand unit is used to determine the index of the water activity. The indirect method of water activity determination is used by the stand unit that is based on pre-setting of the equilibrium relative air humidity through the working space of the unit. The unit flowchart is shown in Fig. 1.

All the unit elements are interconnected through the silicone hose (5) forming the sealed loop. The fan (4) is designed to create the forced air flow in the sealed loop. The sensors of gauges IT5-TR-2 "Termite" (2) are installed in the outlet and inlet to the working chamber (3). The values of the relative air humidity and temperature measured are shown in the display of IT5-TR-2 "Termite" gauge.

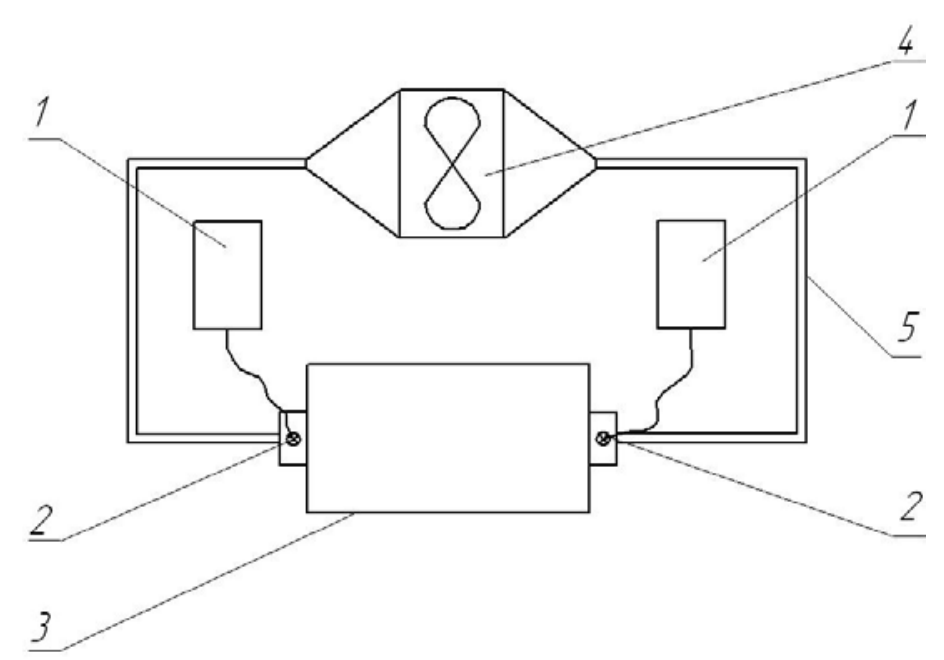

Fig. 1. The flow chart of the stand unit to determine the water activity parameter of food products: $1-$ the IT5-TR-2 "Termite" gauge to measure the relative air humidity and temperature; 2 - sensors of relative air humidity and temperature gauges; 3 - working chamber; 4 - fan; 5 - silicone hose.

The determination of the water activity of food products on the unit consists of two stages: preparatory (draining of the pressure circuit) and primary (setting of equilibrium relative air humidity in the pressure circuit). The volume of water activity $a_{w}$ is found by the formula 2 as follows.

$$
\mathrm{a}_{\mathrm{w}}=\frac{P O B}{100},
$$

where $P O B$ - equilibrium relative air humidity in the pressure circuit, $\%$.
Microbiological parameters are assessed by counting colonies grown in Petri dishes filled with nutrient media. Meat-and-peptone agar, potato and malt agar are used as the culture media. To determine the total contamination of the final product, its aqueous solution is prepared at the ratio of $1: 100,1: 1000$ and $1: 10000$. Each solution prepared is cultured in six Petri dishes. To do so, $0.3 \mathrm{ml}$ of the enzyme solution is taken with the sterile pipette at the burner flame and placed onto the agar surface. Then, the cultured Petri dishes are incubated for $48 \mathrm{~h}$ at $37 \pm 2{ }^{\circ} \mathrm{C}$. 
The content of protein is measured using the total nitrogen (protein) content analyzer "RAPID N ELEMENTAR" that runs by the Dumas' method for sample burning with the total nitrogen content tracing by the thermal conductivity detector. The sample is encapsulated to determine the protein content by the analyzer, wherein the analysis accuracy is $0.5 \%$. The total protein content is calculated by multiplying the total nitrogen in terms of conversion factor for blood proteins that is 6.36 .

The acidity is determined by the activity of hydrogen ions using the potentiometric analyzer. To do so, the test sample is put in the bunsen beaker and an electrode is inserted. The analyzer electrodes do not contact with the beaker walls and bottom. In 10 seconds, the readings are taken as per the instrument scale.

The molecular-mass distribution of proteins and peptides in the resulting hydrolyzates is evaluated by the electrophoretic method in the polyacrylamide gel (PAGE) by the Laemmli method. For this purpose, plates for PAGE polymerization are prepared and the reservoir chambers are filled with the electrode buffer solution (0.066 M Tris, 0.19 M glycine, $0.1 \%$ SDS) for electrophoresis. The previously prepared test sample is put in each well of the gel formed.

The amino acid sequence of the produced peptides is determined using the automated sequencer that runs by the Edman method. This method is based on processing of the test sample with the phenyl isorhodanide resulting in to the abstraction of one amino acid at the $\mathrm{N}$-end of the sequence with its subsequent identification by the liquid chromatography under pressure.

The dry matter content is determined by the refractometer. The sample is pre-diluted with water. The result is multiplied by the dilution coefficient.

\section{RESULTS AND DISCUSSION}

Since blood is the short-life material, its most important parameters are investigated shown in Table 1.
Table 1. Parameters of the stabilized whole blood

\begin{tabular}{|c|c|c|}
\hline \multirow[b]{2}{*}{ Parameter } & \multicolumn{2}{|c|}{ Volume } \\
\hline & $\begin{array}{c}\text { porcine } \\
\text { blood }\end{array}$ & $\begin{array}{c}\text { bovine cattle } \\
\text { blood }\end{array}$ \\
\hline $\begin{array}{l}\text { Mass fraction of } \\
\text { moisture, } \%\end{array}$ & 79.0 & 81.0 \\
\hline Total protein, \% & 22.5 & 17.5 \\
\hline Water activity & 0.99 & 0.99 \\
\hline $\mathrm{pH}$ & 7.85 & 7.55 \\
\hline Hemoglobin, \% & 14.5 & 10.5 \\
\hline $\begin{array}{l}\text { Viscosity relative to } \\
\text { water viscosity }\end{array}$ & 4.3 & 4.2 \\
\hline
\end{tabular}

When developing the stabilizer formulation, the works are based on the principle used to preserve the human blood. It uses $4 \%$ sodium citrate solution or $0.75 \%$ solution of trisodium phosphate. Also, the citric acid is added that favorably affects the native red blood cells and create conditions unfavorable for the microbial growth. The trisodium phosphate solution has a strong waterbinding power to affect the blood, thereby adding to its preservation.

As the basis of the porcine and bovine cattle blood stabilizer to develop, $4 \%$ sodium citrate solution is used and $10 \%$ citric acid solution is used as most appropriate preserving agent with the proportioned concentration to add to the basic stabilizer solution.

In order to control the impact of the citric acid in the stabilized blood on the red blood cell membrane, the concentration of the acid to be added to the main solution is controlled as per the blood $\mathrm{pH}$ upon stabilization. Analysis of the impact caused by the concentration of the the citric acid added to the stabilizer on the blood $\mathrm{pH}$ is shown in Fig. 2.

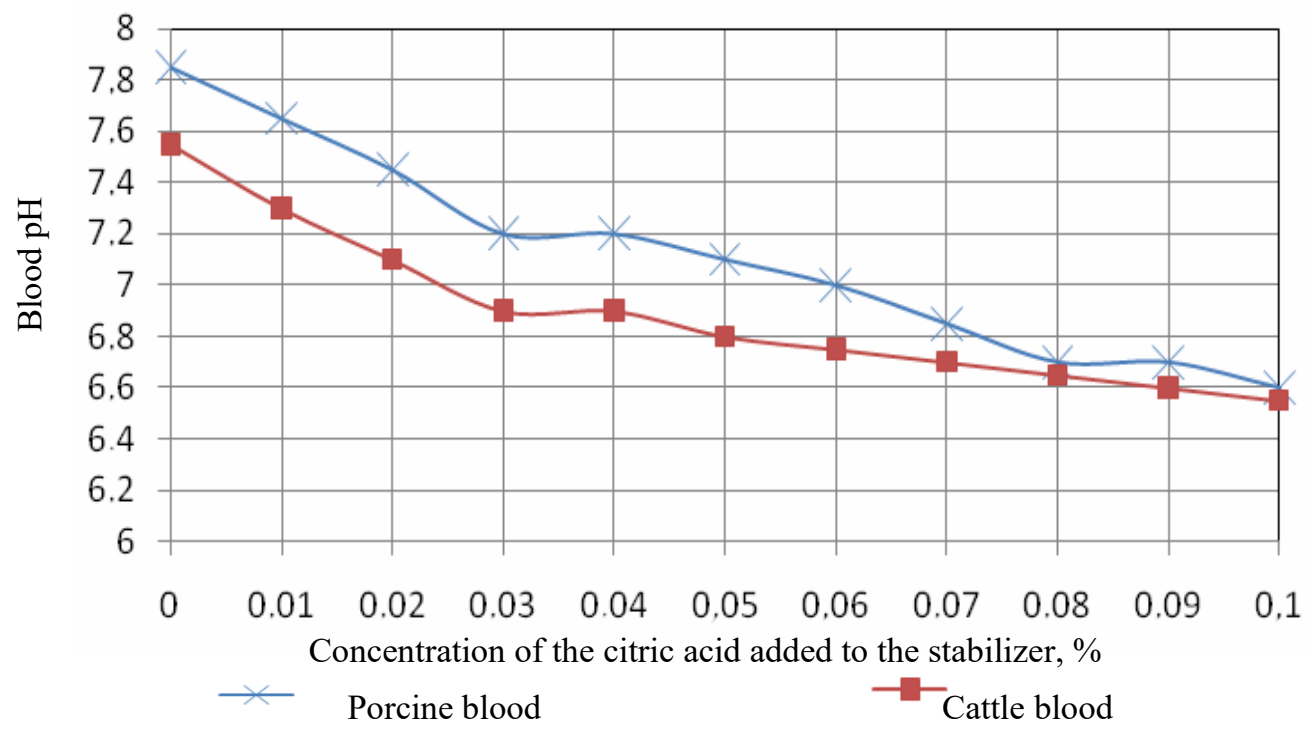

Fig. 2. Dependence of the blood $\mathrm{pH}$ on the concentration of the citric acid added to the stabilizer. 
When adding the stabilizer with the citric acid to the blood, the blood $\mathrm{pH}$ reduction is reported in the porcine and bovine cattle blood to prove the acidity increase.

It should be also taken into account that an increase in the citric acid concentration causes an increase in the blood viscosity, either. The blood viscosity is mainly produced by erythrocyte proteins and plasma proteins to a lesser extent. The blood viscosity is determined in relation to the water viscosity, whereby the standard value corresponds to $4.5 \div 5.0$. The plasma viscosity does not exceed $1.8 \div 2.2$. Thus, of the blood plasma proteins, prothrombin and fibrinogen show the greatest influence on the viscosity volume which present in the blood prior to the fractionation process. Fig. 3 shows the dynamics of the viscosity change in the stabilized whole blood caused by the concentration of citric acid.

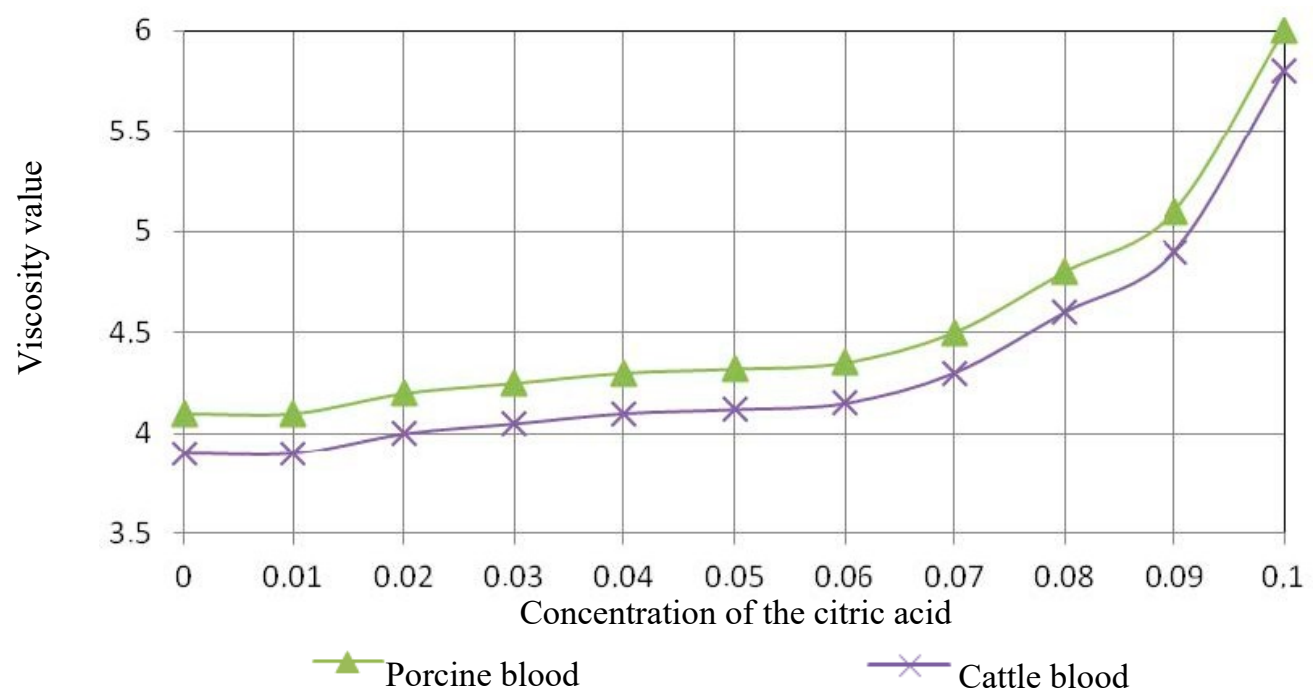

Fig. 3. Dynamics of the viscosity change of the stabilized whole blood caused by the concentration of citric acid.

Data presented in Fig. 2 show that adding the citric acid at the concentration of $0 \div 0.06 \%$ to the stabilized whole blood, its viscosity slightly increases; for the porcine blood, the viscosity is at $4.10 \div 4.35$, and for the bovine cattle blood, it is within $3.90 \div 4$. 15 . In this case, the most stable values are reported with the citric acid concentration of $0.03 \div 0.04 \%$. An increase of the acid concentration results in the change of the slope of curve and at the concentration of $0.1 \%$, the viscosity value for the porcine blood is 6.0 and 5.8 for the bovine cattle blood, which is not desirable since the blood transportation is projected through pipelines prior to its fractionation.

Thus, based on the data obtained for the change in viscosity and blood $\mathrm{pH}$ due to the concentration of citric acid added to the primary stabilizer solution, $10 \%$ citric acid solution of $0.035 \%$ concentration is advisable to use as the additional preserving agent.

Blood is the good nutrient medium for microorganisms. Their vital activity may result in accumulation of protein degradation products in blood. The accumulation of degradation products may give the hemolysis effect, that will cause the destruction of red blood cells and as a consequence, loss of iron. In such conditions, the hemolyzed blood is black. Microbiological studies are performed to understand the action of microorganisms and the effect of additional conservation. They are shown in Fig. 4.

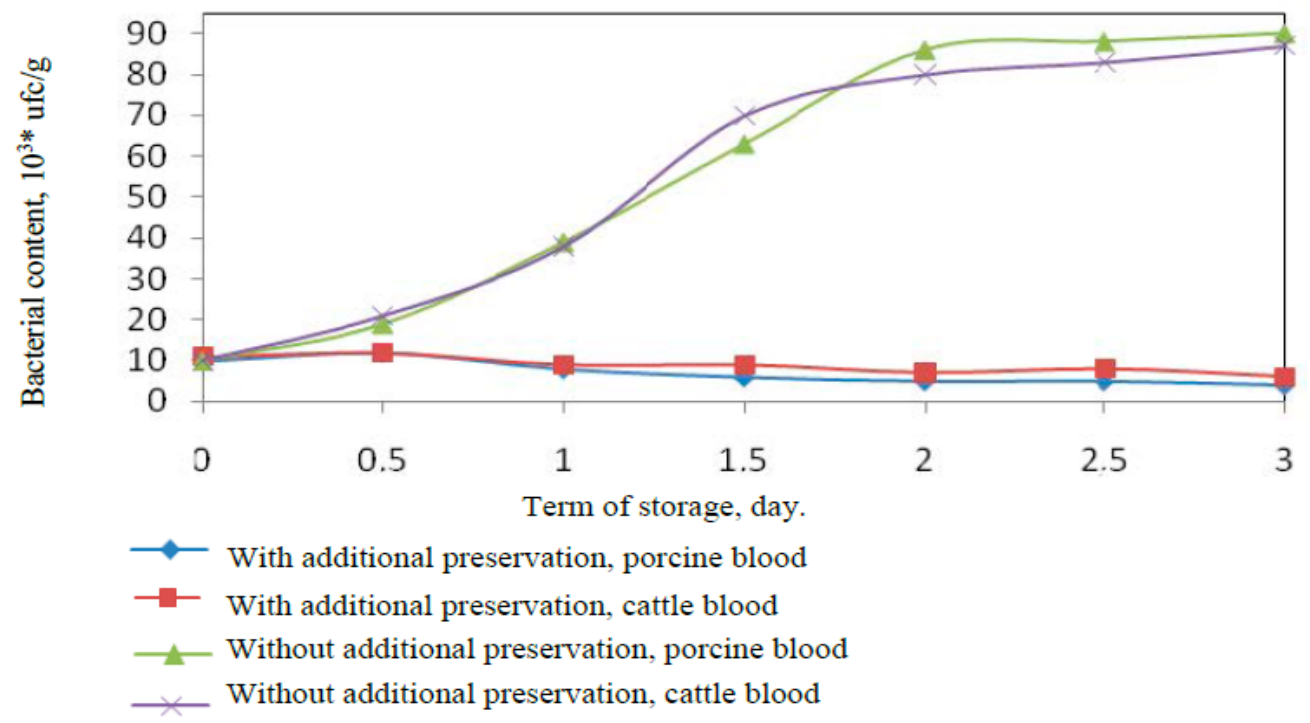

Fig. 4. Dynamics of bacterial growth during storage for the whole stabilized blood with and without additional preservation. 
Based on the data in Fig. 4, it is possible to state the beneficial effects of additional preservation at stabilization.

The main criterion to select the fractionation parameters is the condition to prevent the red blood cells hemolysis prior to hydrolysis. Premature hemolysis is not preferable since it facilitates penetration of hemoglobin molecules to the blood plasma, and, accordingly, it reduces the total hemoglobin count in the red blood cell mass, hence, resulting in non-standard losses. When separating the blood for plasma and red blood cells, the principle of centrifugal acceleration is applied that results in separation of heavier elements (erythrocytes) under the impact. It is therefore the separation factor $(\mathrm{Fr})$ has been selected as the prevailing parameter. And we specifically aimed to achieve the effective separation at the maximum possible low separation factor value. Apart from the selection of the best separation factor, we planned to select the best characteristics for the red blood cells isolation as follow: process length and temperature. These principles are put to the core of the investigation stage to evaluate the dependence on the residual iron in blood plasma upon fractionation on the separation factor as shown in Fig. 5.

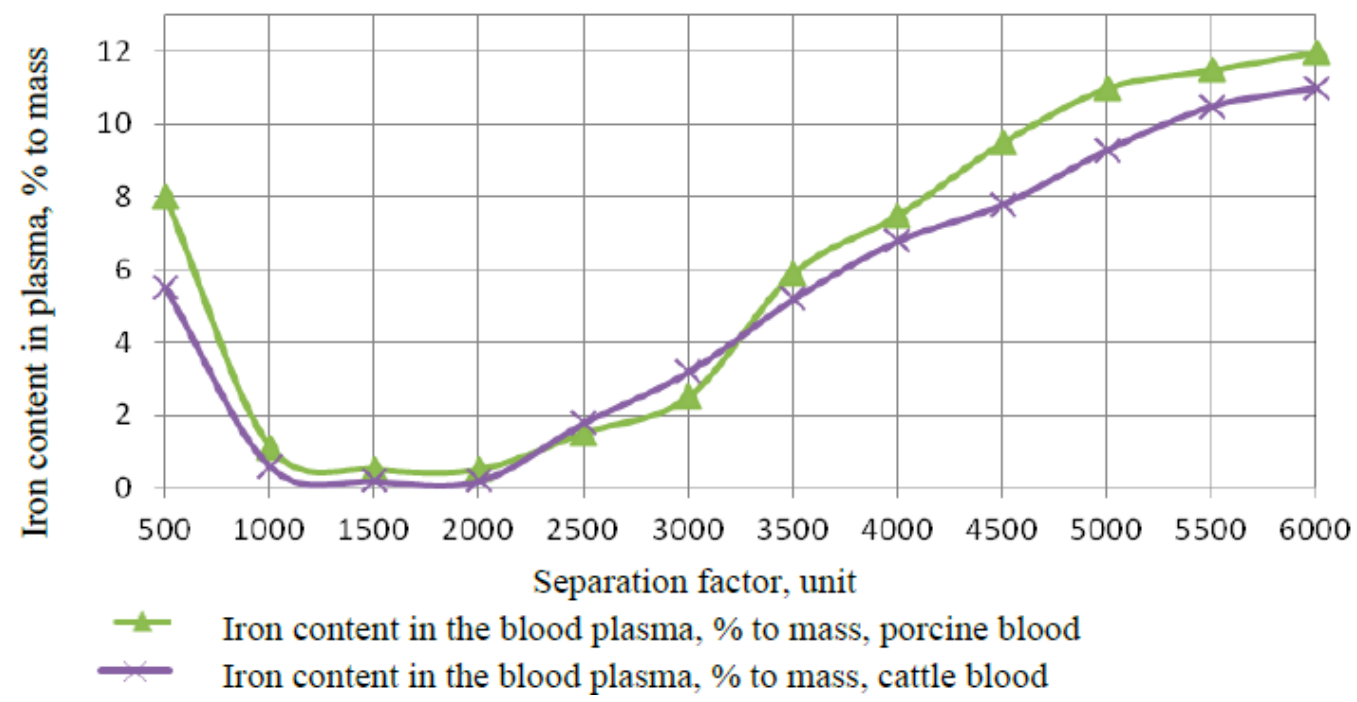

Fig. 5. Dynamic pattern of the residual iron content due to the separation factor applied.

The residual iron content in the blood plasma, as described above, with the separation factor value of less than 1000 units is at the fairly high level, as evidenced by its amount from 1.1 to $8.0 \mathrm{mg} \%$ when separating the porcine blood, and from 0.6 to $5.5 \mathrm{mg} \%$ when separating the bovine cattle blood. The blood fractionation at higher separation factor values results in the initial decrease in the residual amount of plasma iron $(1500 \div 2000$ units) and then in the relatively consistent increase that proves the phenomenon of red blood cells destruction when exposed to higher centrifugal acceleration values. It should be also noted that the least residual amount of red blood cells in the plasma is at the level of $0.5 \mathrm{mg} \%$ for the porcine blood and $0.2 \mathrm{mg} \%$ for the bovine cattle blood and the separation factor value, thus, makes 2000 units.

Further studies are conducted to assess the dependence of the fractionation process on different separation factor values. The studies are shown in the Fig. 6.

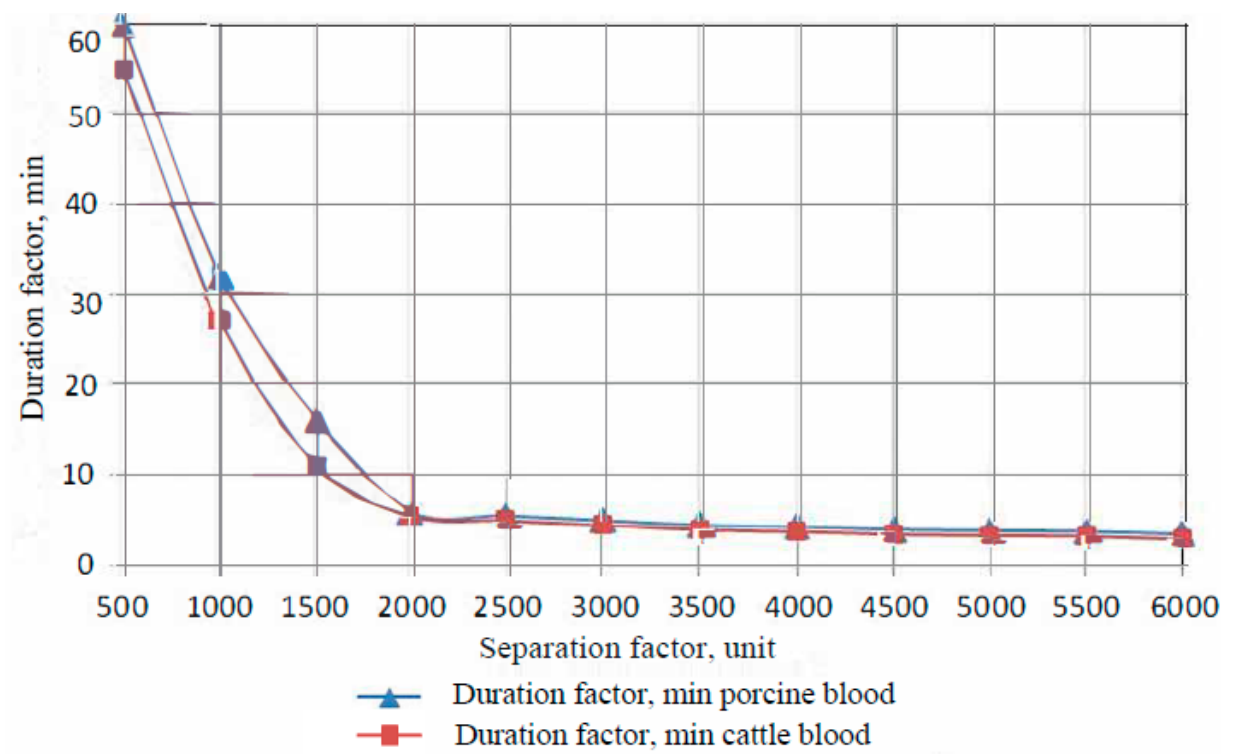

Fig. 6. Dynamic pattern of the separation factor impact on the process length. 
It is seen from the Fig. 5 that the maximum process length for the porcine blood is 60 minutes, and is consistent with the minimum value of the separation factor equal to 500 units. The process length is 55 minutes at the same separation factor for the bovine cattle blood. When reaching the separation factor 2000 units, the length of process for the porcine blood reduces to 6 minutes and to 5.5 minutes for the bovine cattle blood. When the separation factor value is $2000 \div 6000$ units, the processing time slightly decreases that roughly corresponds to the drop from 6 to 3.5 minutes for the porcine blood and from 5.5 minutes to 3.0 minutes - for the bovine cattle blood.
Thus, based on the data obtained for the process length, as well as the zero factor of premature hemolysis and the minimum amount of residual iron in plasma upon fractionation, 2000 units should be taken as the best value for the separation factor.

It should be also taken into consideration that during the primary processing, the blood temperature is close to that of the animal, though the fractionation results in some iron losses associated with the red blood cell hemolysis. To avoid unwanted loss of iron, the temperature at which the minimal losses occur should be calculated. To do so, studies are conducted to evaluate the dependence of the residual iron on the process temperature, shown in the Fig. 7.

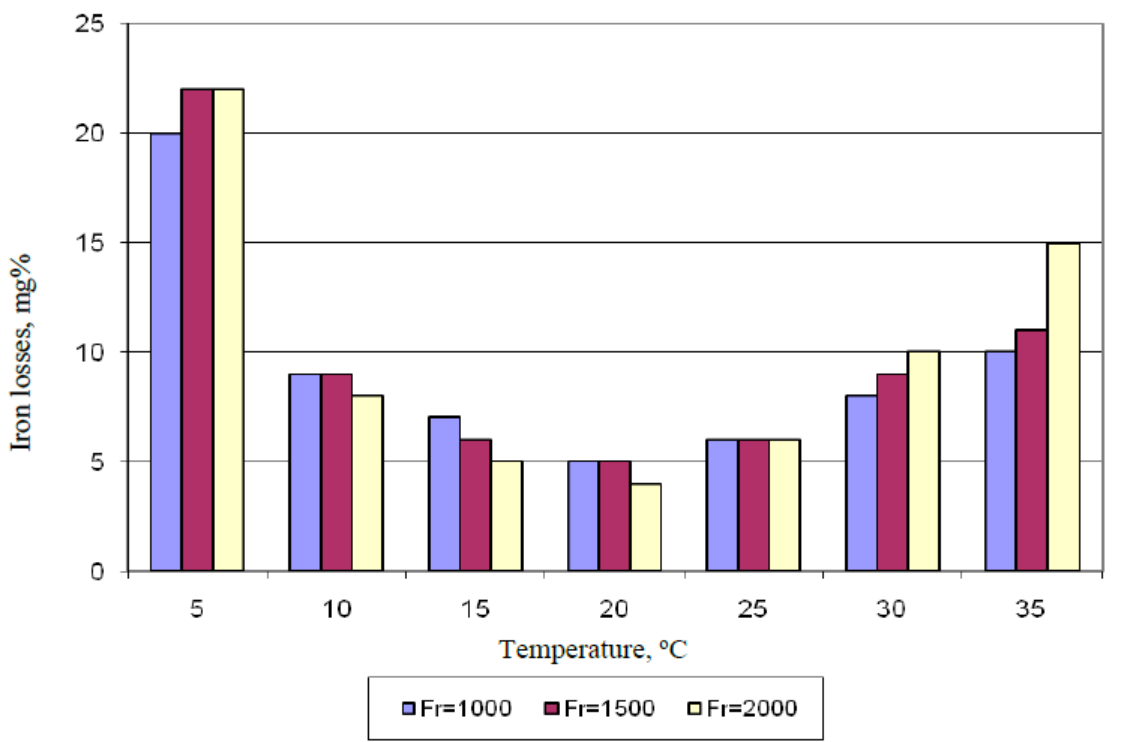

Fig. 7. Dependence of the residual iron on the process temperature.

The data in Fig. 7 show that the best result is reported at the process temperature equal to $20^{\circ} \mathrm{C}$, whereas the least losses are seen at the 2000 units of separation factor.

Hence, we may conclude on the following. The approach that we applied suggests higher rotational speed of fractionation with no significant losses of red blood cells, which is very important. The separation factor value should not exceed 2000 units. Such values is efficient to quickly fractionate the blood. The use of the same separation factor value for the blood of the bovine cattle and pig, due to initial difference in physical properties of their blood, allows to expose the animal blood for different time period, that is 5.5 minutes for the bovine cattle blood and 6 minutes - for the porcine blood.

Parameters to obtain the packed red cells from the bovine cattle and porcine blood have almost the analogous values for the blood of both animal groups. When isolating erythrocytes from blood, the stabilization process should be prioritized that, in this case, followed by the use of additional preservative agent.

Table 2. Parameters to obtain the packed red cells from the whole blood of pigs and bovine cattle

\begin{tabular}{|l|c|c|c|}
\hline $\begin{array}{l}\text { Type of raw } \\
\text { material }\end{array}$ & Stabilizer components & Separation length, min & $\begin{array}{c}\text { Value of separation } \\
\text { factor, units }\end{array}$ \\
\hline Porcine blood & $4 \%$ solution of sodium citrate $+0.035 \%$ solution of \\
citric acid & 6.0 & 2000 \\
\cline { 1 - 3 } $\begin{array}{l}\text { Bovine cattle } \\
\text { blood }\end{array}$ & 5.5 & 2000 \\
\hline
\end{tabular}

Parameters to isolate red blood cells from the blood obtained allow higher rotational speed during fractionation with no significant RBC losses, which is essential for our work. To simplify the principle of developed fractionation parameters in practice, we calculate the relation of the applied rotation speed to the fractionation device (separator, centrifuge) to the radius of rotation of the said device. The calibration curve is shown in Fig. 8.

This curve allows the quick selection of fractionation parameters in view of specification of the separator and in line with the separation conditions selected (separation factor value should not exceed $\mathrm{Fr}=2000)$. 


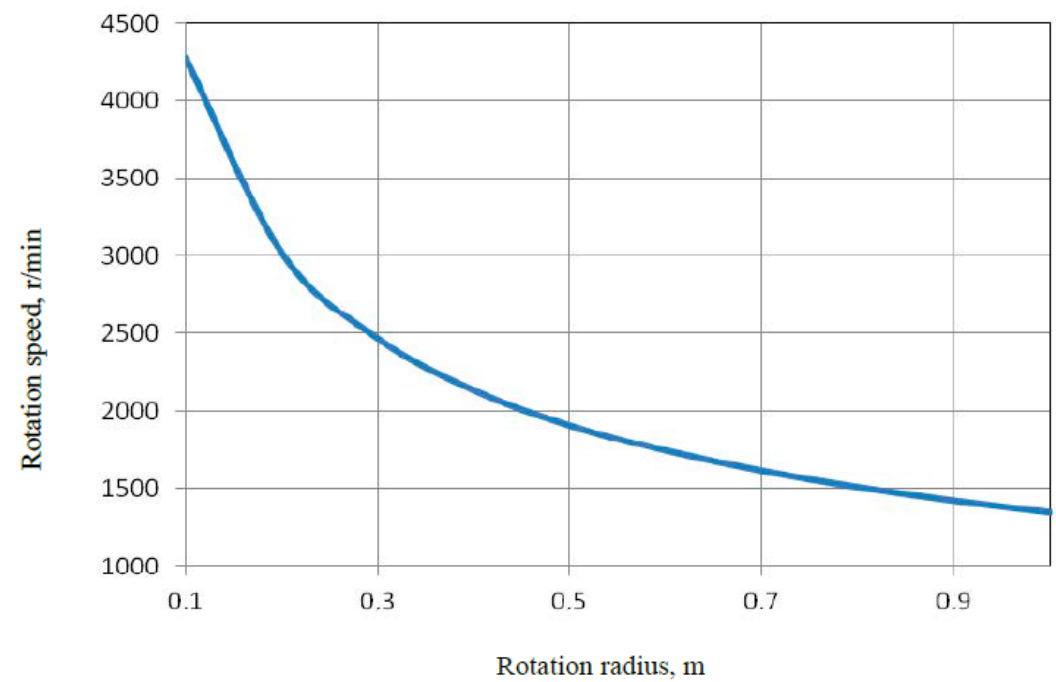

Fig. 8. Calibration curve of the dependence of the separating device velocity (separator, centrifuge) on its rotation radius.

In perspective, we plan to obtain the protein hydrolyzate from the isolated $\mathrm{RBC}$ enriched with the heme iron. It is therefore necessary to understand physical and chemical composition and properties of the raw stock for proposed hydrolysis. Therefore, the study are conducted to evaluate the fractional composition of the obtained RBC protein components of the bovine cattle and porcine bloods. The data is shown in Fig. 9 and Table 3. The Fig. shows the electrophoresis data, and the actual values and the description of isolated fractions of the electrophoretic analysis are tabulated.

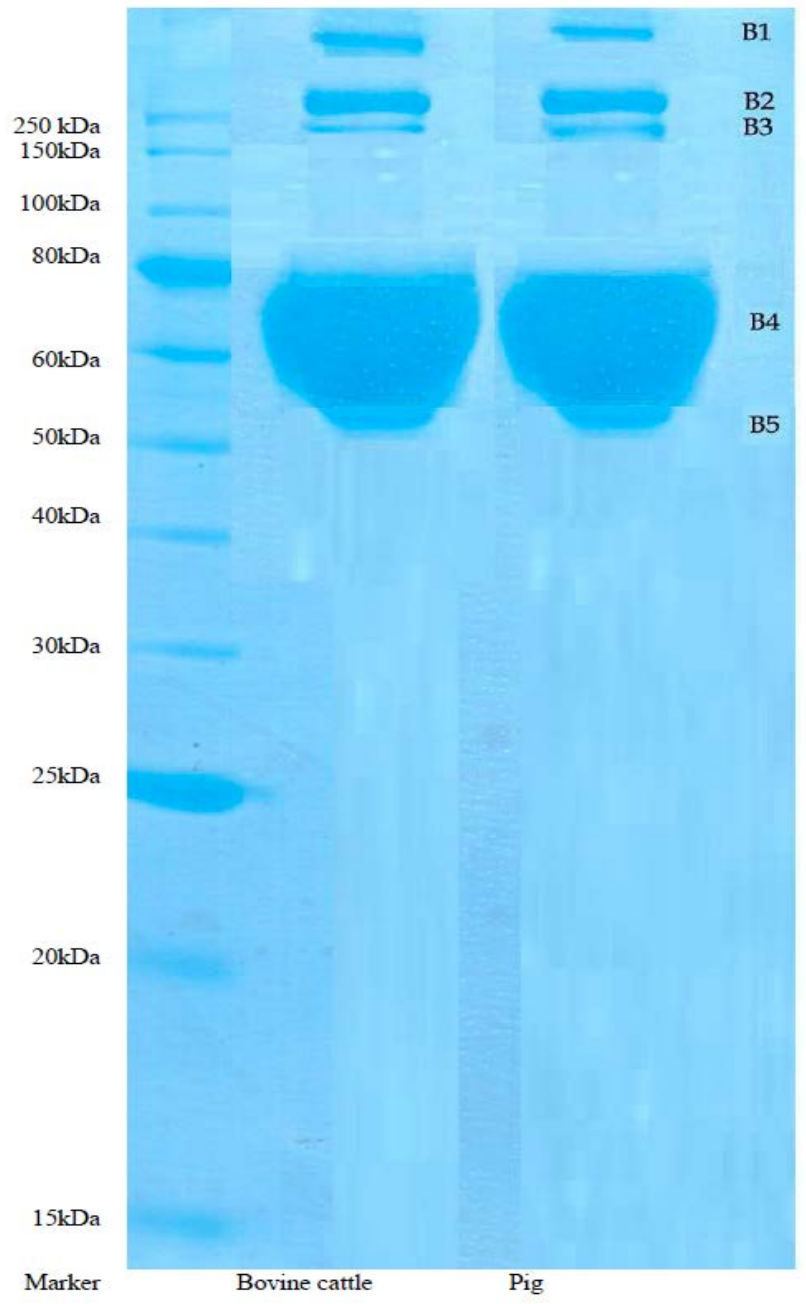

Fig. 9. Polyacrylamide gel electrophoresis data. 
Table 3. Actual values and description of electrophoretic analysis fractions obtained

\begin{tabular}{|c|c|c|c|c|}
\hline \multirow{2}{*}{$\begin{array}{c}\text { Band } \\
\text { number }\end{array}$} & \multirow{2}{*}{ Molecular mass, $\mathrm{kDa}$} & \multicolumn{2}{|c|}{$\%$, of the total protein content } & \multirow{2}{*}{ Fraction } \\
\cline { 3 - 4 } & & Porcine blood RBC & Bovine cattle RBC & Haptoglobin \\
\hline B1 & 854.23 & 1.98 & 4.50 & Fibrinogen \\
\hline B2 & 311.80 & 4.96 & 4.90 & Globulin, one of 3 forms \\
\hline B3 & 208.93 & 2.10 & 1.90 & Hemoglobin \\
\hline B4 & 66.50 & 88.76 & 86.50 & Leucocyte and platelet group protein \\
\hline B5 & 52.54 & 2.20 & 2.20 & \\
\hline
\end{tabular}

The results of fractional study of obtained $\mathrm{RBC}$ protein components in the bovine cattle and porcine bloods prove the benefit of fractionation parameters obtained. RBC fractions of both bovine cattle and porcine blood have the highest values for the hemoglobin protein: molecular mass of $66.50 \mathrm{kDa}$, $88.76 \%$ of the total content for the porcine blood RBC and $86.50 \%$ for the bovine cattle blood RBC. Protein fractions are reported in all fractions with no heme iron in composition. This is the haptoglobin protein with the molecular mass of $854.23 \mathrm{kDa}$, the quantitative content of $1.98 \%$ for the porcine blood RBC and $4.50 \%$ for the bovine cattle blood RBC. Fibrinogen protein is also reported with the molecular mass of $311.80 \mathrm{kDa}$ and the quantitative content of $4.96 \%$ for the porcine blood RBC and $4.90 \%$ for the bovine cattle blood RBC.

One of three forms of globulin available in isolated fractions with the molecular mass of $208.93 \mathrm{kDa}$, the quantitative content of $2.10 \%$ for the porcine blood RBC and $1.90 \%$ for the bovine cattle blood, accordingly. The protein fraction is also reported that may be referred to the leucocyte and platelet group of proteins with the molecular mass of $52.54 \mathrm{kDa}$, the quantitive content of $2.20 \%$ for the porcine and bovine cattle blood RBC.

\section{REFERENCES}

1. Kocherga O.I. Gematogen [Haematogen]. Patent RF, no. 2179227, 2002.

2. Rogov I.A., Zabashta A.G., Kazyulin G.P. Obshchaya tekhnologia myasa i myasoproduktov [General meat and meat product technology]. Moscow: KolosS Publ., 2000. 367 p.

3. Fayvishevskiy M.L. Netraditsionnye tekhnologii pererabotki i ispolzovaniya pishchevoy krovi uboinykh zhyvotnykh [Nonstandard technologies to process and use the slaughter animal blood]. Vsyo o myase [All about meat], 2006, no. 1, pp. 14-17.

4. Salavatulina R. Ratsional'noe ispol'zovanie syry'a v kolbasnom proizvodstve [Rational use of stock in sausage production]. SPb.: GIORD Publ, 2005. 248 p.

5. Kudasheva G.B., Khakimova F.Z., Israfilov A.G., Lyutov A.G., Enikeeva S.A. Sposob polucheniya al'bumina [Albumin production method]. Patent RF, no. 2140287, 1999.

6. Kriger O.V. Advantages of Porcine Blood Plasma as a Component of Functional Drink. Food and Raw Materials, 2014, no. 2, pp. 26-32. doi: 10.12737/5456.

7. Clara S.F. Bah, Bekhit A., Carne A., McConnell M.A. Slaughterhouse Blood: An Emerging Source of Bioactive Compounds Comprehensive Reviews in Food Science and Food Safety, 2013, vol. 12, pp. 314-331. doi: 10.1111/1541-4337.12013.

8. Lafarga T., Wilm M., Wynne K., Hayes M. Bioactive hydrolysates from bovine blood globulins: Generation, characterisation, and in silico prediction of toxicity and allergenicity. Journal of Functional Foods, 2016, vol. 64, no. 8, pp 1741-1750. doi: 10.1021/acs.jafc.5b06078.

\section{Alexandr V. Izgarishev}

Cand.Sci.(Eng.), Scientific Researcher of Scientific - Educational Center, Kemerovo Institute of Food Science and Technology (University), Kemerovo, Russian Federation

\section{Konstantin V. Karchin}

Cand.Sci.(Eng.), Assistant of the Bionanotechnology Department, Kemerovo Institute of Food Science and Technology (University), Kemerovo, Russian Federation

\section{Natalia V. Izgarisheva}

Cand.Sci.(Eng.), Assistant of the Bionanotechnology Department, Kemerovo Institute of Food Science and Technology (University), Kemerovo, Russian Federation 


\title{
GENETIC STRUCTURE OF THE KHAKASS SUB-ETHNIC GROUPS FROM AUTOSOMAL DNA MARKERS AND SURNAMES
}

\author{
Maria B. Lavryashina ${ }^{a, *}$, Marina V. Ul'yanova ${ }^{a}$, Olga A. Balaganskaya ${ }^{b}$, Elena V. Balanovska ${ }^{c}$ \\ ${ }^{a}$ Kemerovo State University, \\ Krasnaya Str. 6, Kemerovo, 650043 Russian Federation \\ ${ }^{\mathrm{b}}$ Vavilov Institute of General Genetics, \\ Gubkina Str. 3, Moscow, 119333 Russian Federation \\ ${ }^{c}$ Research Centre of Medical Genetics \\ Moskvorechie Str. 1, Moscow, 115478 Russian Federation \\ * e-mail:1mb2001@mail.ru
}

Received September 29, 2016;

Accepted in revised form November 11, 2016;

Published December 30, 2016

\begin{abstract}
The authors discussed the results of study of population genetic structure of Khakass sub-ethnic groups - indigenous population of the Republic of Khakassia. The gene pool is studied according to two classes of markers: autosomal DNA (CCR2*rs1799864, CCR5*rs333, ACE1*rs4646994, PLAT*rs4646972, noA25*rs, PV92*rs3138523, ApoA1*rs3138522, no B65*rs, no F13B*rs) and quasigenetic markers (surnames). Total sample size was 249 persons for autosomal DNA dataset, and 9693 persons for the surnames dataset. Four Khakass sub-ethnic groups - Kachins, Koybals, Kyzyls, and Sagays - were investigated. Both classes of markers provided similar results on the subdivision of Khakass sub-ethnic groups and genetic relationships between them. Analysis of autosomal DNA markers showed statistically significant differences of allele frequencies. Interpopulation genetic variation (GST) of the Khakass populations was $2.10 \%$. The largest genetic distances were observed when comparing Sagays and Kyzyls $(\mathrm{d}=0.032)$. The least genetic distances were observed when comparing samples of Kachins and Koybals $(\mathrm{d}=0.032)$. According to the surnames dataset, the similarity index (Ri) is minimal in the pair "Sagays - Kyzyls" and is maximal in a pair of "Kachins - Koybals". Genetic distances characterizing the differences between sub-ethnic groups, decrease, and kinship coefficient, which reflects the similarity increases in the following series: Sagays, Kyzyls, Kachins, and Koybals.
\end{abstract}

Keywords: indigenous population, quasigenetic markers peptides, enzymic hydrolysis, biotechnological methods

DOI: $10.21603 / 2500-1418-2016-1-2-78-84$.

\section{INTRODUCTION}

Work of team headed by Yu.G. Rychkov [1] laid the foundation of intensive research of gene pools of the indigenous peoples of South Siberia. Since then, a huge amount of data was accumulated characterizing the population genetic structure of the South Siberian peoples according to different genetic systems: autosomal DNA markers [2, 3], mitochondrial DNA markers [4, 5], Y-chromosome markers [6-9], X chromosome markers [10], quasigenetic markers - surnames [11, 12]. Formed biobanks and databases of Siberian population gene frequencies are increasingly in demand by the international scientific community [13] to solve the fundamental [14] and applied [15] problems. The result of these studies was understanding of necessity to study the small-numbered nations (in this article, we will use the term "sub-ethnos" to refer to them), joined under territorial exoethnonyms.

Exoethnonyms such as "Altaians", "Khakass", and "Shors" are names of the indigenous population of various geographical areas - the Altai-Sayan highlands, Khakass-Minusinsk hollow, Mountain Shoria. At the same time the modern Altaians population includes four sub-ethnic groups having the status of indigenous peoples - Kumandins, Telengits, Tubalars, Chelkans and fifth - the title for the Republic of Altai - the Altai-Kizhi. Khakass include four sub-ethnic groups - Kachins, Koybals, Kyzyls, and Sagays. Shors have two sub-ethnic groups - mountain taiga and Abakanian. It is obvious that in the recent past namely the small-numbered peoples reflected features of population of Southern Siberia, so the analysis of gene pools of smallnumbered peoples may open a new page in its ethnic history and microevolution of its populations. Khakass is the indigenous population of the Republic of Khakassia (hereinafter - RK). Emergence of the ethnic term "Khakass" and validity of its use as a selfdesignation of South Siberian Turks of the KhakassMinusinsk hollow causes debates in historical and ethnographic environment. According to some researchers, this term is endogenous, as it existed previously as the name of one of the oldest ethnic groups - ethnonym "Khakass" was mentioned in the Chinese written sources of the VI - XII centuries [16]. According to another view, it is exoethnonyms, and its implementation as a self-designation of ethnic genetics of RK is artificial. [17]

Please cite this article in press as: Lavryashina M.B., Ul'yanova M.V., Balaganskaya O.A., Balanovska E.V. Genetic structure of the Khakass subethnic groups from autosomal DNA markers and surnames. Science Evolution, 2016, vol. 1, no. 2, pp. 78-84. doi: 10.21603/2500-1418-2016-1-2-78-84. Copyright (C) 2016, KemSU. This is an open access article distributed under the terms of the Creative Commons Attribution 4.0 International License (http:// creativecommons.org/licenses/by/4.0/), allowing third parties to copy and redistribute the material in any medium or format and to remix, transform, and build upon the material for any purpose, even commercially, provided the original work is properly cited and states its license. This article is published with open access at http:/ science-evolution.ru/ 
The process of formation of Khakass ethnos included several stages. "Kyrgyz" stage is connected with the existence of the Kyrgyz State (VI-XIII centuries). The Yenisei Kyrgyz, one of the ancient cultural peoples of Central Asia, were among the ancestors of the modern Khakass and Kyrgyz people, and dispersed among many stock-raising peoples of the Sayano-Altai. "Hongoray" stage [18] covers formation of Khakass composed of several principalities (XIV-XVIII centuries). "Russian" stage began after accession of Khakass to Russia (XVIII XXI centuries). "Russian" stage is characterized by pronounced consolidation of indigenous population of the Khakass-Minusinsk hollow under official ethnonym "Khakass" within the province, district, county, autonomous region and, finally, the Republic of Khakassia.

Division of Khakass into modern Kachins, Sagays, Koybals, and Kyzyls was accepted at the beginning of the XVIII century and was based on names of the largest Khakass seoks: khaas, sagay, khoybals, khyzyl [19]. However, formation of these sub-ethnic groups has its roots in the period preceding appearance of Russian people on the Yenisei River [20] Kachins, which included seoks (genus) such as yzyr, pyuryut, sohs, khaskha, kyrgyz, and others, dominated politically and economically, and thus became the center of the consolidation processes of Khakass in the XVIII-XIX centuries. Kyzyls formed on the basis of Turkic-speaking population of valleys of White and Black Iyus, and Chulym. Formation of Koybals proceeded on the basis of the Turkic-speaking tribes and their assimilation of Samoyed and Ket-speaking population of the right bank of the Yenisei River. Koybals originally formed under the influence of Kachins, but since 1858, after the integration of their territories into the Sagayskaya Duma, their convergence with Sagays and Beltyrs intensified. By the end of the XIX century Beltyrs become to move closer to Sagays who expanded their territory at the expense of assimilation of population living on the left tributaries of the river Abakan, and in the XX century the ethnicon "sagays" spread to Beltyrs. Descendants of Birusins and Shors were also involved in the formation of the sagay group [20].

Official population censuses indicate the number of Khakass in Russia: as of 2002 - 75.6 thousand people, as of 2010 - 72.9 thousand people, including in the Republic of Khakassia - 63.6. All-Russian population censuses do not considered Khakass belonging to individual sub-ethnic groups. According to the calculated data [21], at the beginning of the XXI century, Sagay subethnic group dominates numerically, but four sub-ethnic group still persist and have areas of compact dwelling: Kachins and Kyzyls - Ordzhonikidze and Shirinsky districts of RK, Koybals - Beysky district of RK, Sagays Askizsky and Tashtypsky districts of RK (Fig. 1). Currently, Khakass people are characterized by significant inter-ethnic mixing, as a result of marriages between members of individual sub-ethnic groups, as well as the common tendency to the loss of self-designations Kachins, Kyzyls, Koybals, and Sagays.

According to the physical anthropology data, Khakass are generally classified as South Siberian Mongoloids, but their sub-ethnic groups are heterogeneous: The South Siberian variant is predominating among Kachins and Koybals, and is noticeably weakened among Sagays and Kyzyls [22]. With regard to ethnic genetics, a problem about genetic reality of the existence of Khakass subethnic groups is still open. Previously we have investigated the gene pools of Kachins, Koybals, and Sagays according to data on Y-chromosome polymorphism - one of the most informative genetic systems in the arsenal of ethnic genetics and ethnic genetics $[9,23]$. The results obtained indicate a significant genetic subdivision of Khakass sub-ethnic groups $\left(\mathrm{F}_{\mathrm{ST}}=30.3 \%\right)$ : the Khakass gene pool is a leader among the peoples of South Siberia in the degree of heterogeneity.

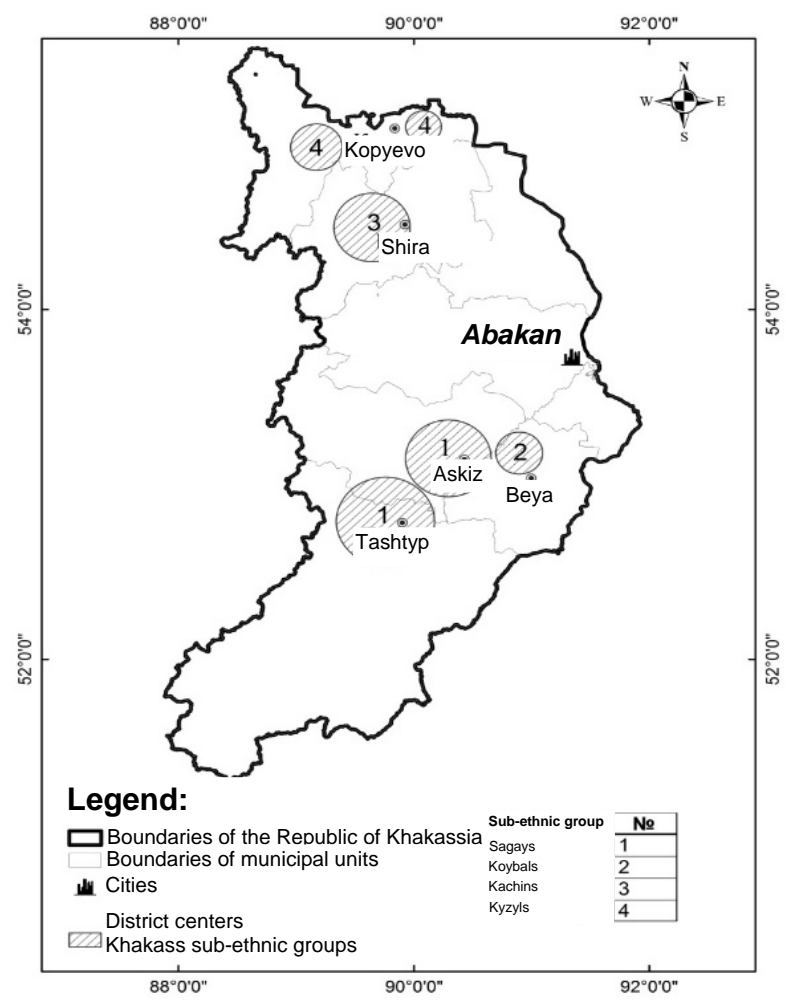

Fig. 1. The main areas of compact dwelling of Khakass sub-ethnic groups in the Republic of Khakassia. 